\title{
Seasonal variations of 25-OH vitamin D serum levels in Multiple Sclerosis patients with relapse using MRI
}

\author{
Sharareh Sanei Sistani (1), Ali Moghtaderi (2), Ali Reza Dashipoor (3), Maryam \\ Ghaffarpoor (1), Bahareh Heshmat Ghahderijani (1)
}

(1) Department of Radiology, School of Medicine, Zahedan University of Medical Sciences, Zahedan, Iran; (2) Department of Neurology, Zahedan University of Medical Sciences, Zahedan, Iran; (3) Department of Nutrition and Food Sciences, Zahedan University of Medical Sciences, Zahedan, Iran

This article is distributed under the terms of the Creative Commons Attribution Noncommercial License (CC BY-NC 4.0) which permits any noncommercial use, distribution, and reproduction in any medium, provided the original author(s) and source are credited.

\begin{abstract}
An increasing body of evidence suggests that low vitamin D (25-[OH]-D) concentrations is linked to increased activity in multiple sclerosis (MS) patients and MS relapse. Therefore, the current study was aimed to evaluate vitamin D serum concentrations and its possible seasonal variations among MS patients with relapse. This prospective, descriptive study was conducted on patients with MS relapse who referred to the neurology center of Ali ibn Abi Talib Hospital in Zahedan during one year. Magnetic Resonance Imaging (MRI)-Spine was performed for 90 patients and serum samples were collected from patient to measure serum vitamin D levels using RIA KIT. Furthermore, the plaques in each patient's MRI were counted and then recorded. Descriptive and inductive statistics were conducted using statistical software. Our findings indicated a significant correlation between serum vitamin $D$ level and cervical spinal cord plaques ( $\mathrm{p}=0.007, \mathrm{r}=0.28$ ), while no association was revealed between serum vitamin $\mathrm{D}$ level and number of brain plaque. Furthermore, a significant association was also observed between number of cervical spinal cord plaques and serum vitamin D levels. In addition, a reverse correlation was observed between number of cervical spinal cord plaques and serum vitamin D levels in spring. In autumn, there was a statistically significant relationship between number of brain plaque and serum vitamin D level. Additionally, a statistically significant relationship was found between serum vitamin D levels and number of plaques in winter. Our findings are in agreement with some previous studies that reported conflicting result, where the association of season with the prevalence of relapse cases cannot be verified. Although the mean serum levels of vitamin D are inversely correlated with the incidence of relapses in winter. However, the values obtained in the spring do not confirm such an inverse relationship.
\end{abstract}

Key Words: Vitamin D, Magnetic Resonance Imaging, Multiple sclerosis, serum.

Eur J Transl Myol 29 (3): 268-275, 2019

Multiple sclerosis (MS) is a demyelinating disorder characterized by selective inflammation and degeneration of central nervus system (CNS) myelin. MS is characterized by a syndrome consisting of inflammation, demyelination and gliosis. ${ }^{1}$ MS plaques are typically round or oval, which are seen in the preventricular region or ependymal region, especially in the occipital horn. Although imaging should never be considered alone for diagnosis, the MRI is the most sensitive indicator to find MS plaques. ${ }^{2}$ The causes of the difference in the incidence of multiple sclerosis in the world are uncertain, but genetic and environmental factors (i.e., sun exposure) may be involved in demyelinating events and relapse probability. ${ }^{3-5}$

The incidence of MS is also reported to be remarkably associated with geographical location, when MS is more frequently occurred in both northern and southern areas of the northern and southern hemispheres. ${ }^{6-8}$ An increasing body of evidence suggests that levels of vitamin D (25-[OH]-D) have latitudinal and seasonal variations, depending on the sunlight exposure. ${ }^{4}$ Vitamin $\mathrm{D}$ deficiency has been indicated to be linked to different adverse health outcomes such as MS relapse, and its activity on MRI. ${ }^{9-11}$ Although early studies have shown contradictory results, ${ }^{12-17}$ current evidence suggests 
Table 1. Comparison of mean serum vitamin D levels in terms of seasons

\begin{tabular}{|c|c|c|c|c|c|c|}
\hline Season & $\begin{array}{c}\text { Mean } \\
(\mathbf{m m o l} / \mathbf{L})\end{array}$ & $\begin{array}{c}\text { Standard } \\
\text { deviation }(\mathbf{S D})\end{array}$ & $\begin{array}{c}\text { Minimum } \\
(\mathbf{m m o l} / \mathbf{L})\end{array}$ & $\begin{array}{c}\text { Maximum } \\
(\mathbf{m m o l} / \mathbf{L})\end{array}$ & Number & p-value \\
\hline Spring & $\mathbf{2 8 . 9 5}$ & $\mathbf{1 2 . 5 2}$ & $\mathbf{1 2 . 0 1}$ & $\mathbf{5 9 . 9 7}$ & 32 & \\
\hline Summer & $\mathbf{2 2 . 2 5}$ & $\mathbf{1 2 . 0 2}$ & $\mathbf{1 2 . 0 6}$ & $\mathbf{4 0 . 1 0}$ & 15 & \\
\hline Autumn & $\mathbf{2 1 . 4 4}$ & $\mathbf{1 0 . 5 8}$ & $\mathbf{1 2 . 1 6}$ & $\mathbf{4 6 . 7 0}$ & 26 & $\mathbf{0 . 0 1 2}$ \\
\hline Winter & $\mathbf{3 3 . 8 5}$ & $\mathbf{1 8 . 4 0}$ & $\mathbf{1 2 . 1 4}$ & $\mathbf{6 6 . 4 5}$ & 17 & \\
\hline Total & $\mathbf{2 6 . 5 9}$ & $\mathbf{1 3 . 8 8}$ & $\mathbf{1 2 . 0 7}$ & $\mathbf{6 6 . 4 5}$ & 90 & \\
\hline
\end{tabular}

seasonal variations of relapse rates. ${ }^{18-21}$ The current study aims to evaluate vitamin D serum concentrations and its possible seasonal variations among MS patients in a neurology center.

\section{Materials and Methods}

This prospective, descriptive study was performed on patients with MS relapse who referred to the neurology center of Ali ibn Abi Talib Hospital in Zahedan during one year. All patients with MS were enrolled according to McDonald criteria. Furthermore, all patients with vitamin D supplementation within one year before referral were excluded from the study. In addition, informed consent form was taken from patient for participating in the study. Magnetic Resonance Imaging of spine was performed for 90 patients and a serum sample was obtained from each patient to measure serum vitamin D levels and then kept at $-20^{\circ} \mathrm{C}$. The plaques in each patient's MRI were counted and recorded. At the end of the one-year period, the serum levels of vitamin D in each patient's blood samples were measured by immunoassay method. Accordingly, MS patients were those who were clinically diagnosed with McDonald criteria, including visual, somatosensory and motor evoked potentials, CSF analysis for oligoclonal bands, immunoglobulin G index, and Myelin basic protein. The findings were confirmed by a MS diagnostic neuroscientist, or the history of two or more MS attacks and a neurologist diagnosis was adequate. MRI was performed immediately after administration of gadolinium DTPA (1.0 mmol / kg). The brain and spinal cord MRI include T2WIS, T1WIS, which T1-WIS with gadolinium contrast infusion (MT) was used due to the consideration of acute lesions. Eighteen brain sections were taken from the brain in three sections including axial, sagittal and coronal with a thickness of approximately $5 \mathrm{~mm}$ (field view: $450 \times 240 \mathrm{~mm}$; matrix image: 512 x $256 \mathrm{~mm}$, and pixel: $0.94 \mathrm{~mm} 2$ ). In the two axil and sagittal sections, 18 sections were made from the spinal cord with an approximate thickness of about $5 \mathrm{~mm}$ (Simpson et al, 2010). ${ }^{4}$ The serum samples were collected from the patients and then kept at $-20^{\circ} \mathrm{C}$ until use. Measurement of $25(\mathrm{OH})$ D serum values was performed using RIA KIT.

\section{Data analysis}

One-way ANOVA test was used to compare the serum level of vitamin D in different seasons of the year. To determine the difference in mean of vitamin $D$ in different groups, posthoc Tukey test was used. Spearman's rank correlation coefficient was applied to compare the relationship between serum vitamin D levels and number of brain and cervical spinal cord plaques. Furthermore, chi-square test was used to investigate the

Table 2. Relationship of serum vitamin D levels with brain and cervical spinal cord plaques and total plaques

\begin{tabular}{|c|c|c|}
\hline \multicolumn{2}{|c|}{} & Serum Vitamin D levels \\
\hline \multirow{2}{*}{ Brain plaque } & The correlation coefficient & $\mathbf{- 0 . 1 0 6}$ \\
\cline { 2 - 3 } & p-value & $\mathbf{0 . 3 2 1}$ \\
\cline { 2 - 3 } & Number of patients & 90 \\
\hline \multirow{2}{*}{ Cervical spinal cord plaque } & The correlation coefficient & $\mathbf{- 0 . 2 8 1}$ \\
\cline { 2 - 3 } & p-value & $\mathbf{0 . 0 0 7}$ \\
\cline { 2 - 3 } & Number of patients & 90 \\
\hline \multirow{2}{*}{ Total plaques } & & $-\mathbf{0 . 1 8 8}$ \\
\cline { 2 - 3 } & The correlation coefficient & $\mathbf{0 . 0 7 7}$ \\
\cline { 2 - 3 } & p-value & $\mathbf{9 0}$ \\
\cline { 2 - 3 }
\end{tabular}


Table 3. Comparison of the frequency of brain plaque status based on the seasons

\begin{tabular}{|c|c|c|c|c|c|}
\hline Season & $\begin{array}{c}\text { Frequency } \\
\text { Yes }\end{array}$ & $\begin{array}{c}\text { Percent } \\
\text { Yes }\end{array}$ & $\begin{array}{c}\text { Frequency } \\
\text { No }\end{array}$ & $\begin{array}{c}\text { Percent } \\
\text { No }\end{array}$ & Total \\
\hline Spring & 25 & 78.8 & 8 & 21.2 & 32 \\
\hline Summer & 11 & 73.3 & 4 & 26.7 & 15 \\
\hline Autumn & 24 & 92.6 & 2 & 7.4 & 26 \\
\hline Winter & 14 & 82.4 & 3 & 17.6 & 17 \\
\hline Total & 76 & $\mathbf{8 2 . 6}$ & 16 & 17.4 & 90 \\
\hline
\end{tabular}

Table 4. Comparison of the frequency of cervical spinal cord plaques in terms of seasons

\begin{tabular}{|c|c|c|c|c|c|}
\hline Season & $\begin{array}{c}\text { Frequency } \\
\text { Yes }\end{array}$ & $\begin{array}{c}\text { Percent } \\
\text { Yes }\end{array}$ & $\begin{array}{c}\text { Frequency } \\
\text { No }\end{array}$ & $\begin{array}{c}\text { Percent } \\
\text { No }\end{array}$ & Total \\
\hline Spring & 8 & 25 & 24 & 73.3 & 32 \\
\hline Summer & 4 & 26.7 & 11 & 73.3 & 15 \\
\hline Autumn & 8 & 30.76 & 18 & 60.23 & 26 \\
\hline Winter & 5 & 29.4 & 12 & 70.6 & 17 \\
\hline Total & $\mathbf{2 5}$ & $\mathbf{2 7 . 7 7}$ & $\mathbf{6 5}$ & 73.33 & 90 \\
\hline
\end{tabular}

relationship between serum vitamin D level and cervical plaque status. One-sample chi-square test was used to compare the seasonal relapse of the diseas.. Spearman's rank correlation coefficient was employed to determine the relationship between serum vitamin D level and total number of plaques. Statistical significance was considered as $\mathrm{p}<0.05$.

\section{Results}

Of the 90 patients referred, the number of relapses in the spring, summer, autumn and winter seasons was as follows: 26 (28.88\%), 15 (16.66\%), 32 (35.55\%), and 17 (18. 89\%). Plaques were ranged between 0 and 6 for brain plaque and 0 to 3 for spinal cord plaques. At the end of the one-year period, the serum vitamin D levels in the blood samples were measured by ELISA method. The mean serum levels of vitamin D in the spring, summer, autumn and winter seasons were 28.95, 44.25, 21.22, $33.85 \mathrm{mmol} / \mathrm{L}$ (Table 1 ). The mean total serum vitamin $\mathrm{D}$ level was $26.59 \mathrm{mmol} / \mathrm{L}$, ranging from 12.01 to 66.45 $\mathrm{mmol} / \mathrm{L}$, with a standard deviation of 13.88. One-way ANOVA was used to compare the serum level of vitamin $\mathrm{D}$ in different seasons of the year. Results showed significant differences in vitamin $\mathrm{D}$ levels $(\mathrm{P}=0.012$; Table 1). To determine the difference between mean serum vitamin D level, posthoc Tukey test was used. Results showed that vitamin D level $(21.44 \mathrm{mmol} / \mathrm{L})$ was significantly lower than winter $(33.85 \mathrm{mmol} / \mathrm{L}$; $\mathrm{p}$ $=0.018$ ). Spearman's rank correlation coefficient was used to compare the association between serum vitamin $\mathrm{D}$ levels and number of brain and cervical spinal cord plaques in MRI. There was a significant correlation between serum vitamin D level and cervical spinal cord plaques $(p=0.007, r=0.28)$, while no relationship was found between serum vitamin $\mathrm{D}$ level and number of brain plaque ( $\mathrm{p}=0.32, \mathrm{r}=-0.10$; Table 2 ). In addition, there was a significant relationship between the number of brain plaques and cervical spinal cord plaques in MRI ( $\mathrm{p}<0.001 ; \mathrm{r}=0.48$ ). Chi-square test showed no significant relationship between the status of plaque and the season for both brain and cervical spinal cord plaques $(p=0.33 ; p=0.99)$, (Tables 3 and 4). One-sample chisquare test was used to compare the relapse of the disease according to the seasons. The results showed that the relapse of the disease in various seasons was statistically different ( $\mathrm{p}=0.025)$, so that the most relapse was seen in the spring (32cases, 35.55\%) and the lowest in the summer (15 cases, $16.66 \%$ ). Spearman's rank correlation test showed a significant correlation between number of cervical spinal cord plaques and serum vitamin D levels. Furthermore, a reverse correlation between number of cervical spinal cord plaques and serum vitamin D levels was observed in spring ( $\mathrm{P}=0.009 ; \mathrm{r}=-0.45$; Table 5); however, there was no statistically significant correlation 
Table 5. Relationship of serum vitamin D level with brain, cervical spinal cord and total plaques in spring

\begin{tabular}{|c|c|c|}
\hline \multicolumn{2}{|c|}{} & Serum Vitamin D levels \\
\hline \multirow{2}{*}{ Brain plaque } & The correlation coefficient & $\mathbf{- 0 . 2 6 9}$ \\
\cline { 2 - 3 } & p-value & -.136 \\
\cline { 2 - 3 } & Number of patients & 32 \\
\hline \multirow{2}{*}{ Cervical spinal cord plaque } & The correlation coefficient & $\mathbf{- 0 . 4 5 7}$ \\
\cline { 2 - 3 } & p-value & $\mathbf{0 . 0 0 9}$ \\
\cline { 2 - 3 } & Number of patients & 32 \\
\hline \multirow{2}{*}{ Total plaques } & & $-\mathbf{0 . 3 0 9}$ \\
\cline { 2 - 3 } & The correlation coefficient & $\mathbf{0 . 0 8 5}$ \\
\cline { 2 - 3 } & pumber of patients & 32 \\
\cline { 2 - 3 } & & \\
\hline
\end{tabular}

Table 6. Relationship of serum vitamin D level with brain, cervical spinal cord and total plaques in summer

\begin{tabular}{|c|c|c|}
\hline \multicolumn{2}{|c|}{} & Serum Vitamin D levels \\
\hline \multirow{3}{*}{ Brain plaque } & The correlation coefficient & $\mathbf{- 0 . 0 4 7}$ \\
\cline { 2 - 3 } & p-value & $\mathbf{0 . 8 6 9}$ \\
\cline { 2 - 3 } & Number of patients & $\mathbf{1 5}$ \\
\hline Cervical spinal cord plaque & The correlation coefficient & $\mathbf{- 0 . 2 2 1}$ \\
\cline { 2 - 3 } & p-value & $\mathbf{0 . 4 2 8}$ \\
\cline { 2 - 3 } & Number of patients & $\mathbf{1 5}$ \\
\hline \multirow{2}{*}{ Total plaques } & & $\mathbf{- 0 . 0 4 0}$ \\
\cline { 2 - 3 } & The correlation coefficient & $\mathbf{0 . 0 8 6}$ \\
\cline { 2 - 3 } & P-value & $\mathbf{1 5}$ \\
\cline { 2 - 3 } & Number of patients & \\
\hline
\end{tabular}

in summer (Table 6). In autumn, there was a statistically significant relationship between number of brain plaque and serum vitamin D level $(\mathrm{p}=0.04 ; \mathrm{r}=0.39$; Table 7). In winter, there was a statistically significant relationship between serum vitamin D levels and number of plaques (i.e., brain and cervical spinal cord plaques, as well as total plaques; $\mathrm{P}=0.36, \mathrm{r}=-0.5 ; \mathrm{p}=0.001, \mathrm{R}=-0.71 ; \mathrm{p}=$ $0.001, \mathrm{r}=0.71)$, (Table 8).

\section{Discussion}

Different genetic and environmental factors are capable increasing the risk of MS such latitude, altitude, bioclimatic variables, vitamin D, smoking, infection with Epstein Barr virus (e.g., clouding and ozone levels, etc.,) nevertheless, the impact of each variable alone is not clear. $^{22-27}$ The correlation of vitamin D levels with MS relapse was reported previously. It has been indicated that vitamin D is capable of modulating both innate and adaptive immune responses. It is capable of modulating Antigen-presenting cells (APCs) that are involving in reduction of auto-aggressive $\mathrm{T}$ cells activation. ${ }^{28-32}$ Vitamin D plays a role in suppressing $\mathrm{B}$ cell and $\mathrm{T}$ cell differentiation. ${ }^{33-35}$ The role of VD-associated genes or certain genetic interference with VD is still not fully understood. ${ }^{35}$ More recent evidence indicated latitudinal and seasonal variations of vitamin $\mathrm{D}$, depending on the sunlight exposure, 4 therefore, Vitamin D deficiency is potentially involved in the risk of MS, and its relapse. ${ }^{9,11,36,37}$ Our findings showed a seasonal variation in MS relapse with a peak in spring, while the lowest rate was observed in summer and autumn. The high incidence of relapse in the spring and autumn could be due to the involvement of other environmental factors, including infections that are capable of affecting the host's immune system, these interpretation is reminiscent of the results by Ogawa et al., 2004. ${ }^{20}$ They indicated that total number of attacks was frequently increased in the warmest and coldest months. Heat in hot seasons can be considered as 
Table 7. Relationship of serum vitamin D level with brain, cervical spinal cord and total plaques in autumn

\begin{tabular}{|c|c|c|}
\hline \multirow{2}{*}{ Brain plaque } & Serum Vitamin D levels \\
\hline \multirow{2}{*}{ Cervical spinal cord plaque } & The correlation coefficient & $\mathbf{- 0 . 3 9 8}$ \\
\cline { 2 - 3 } & Number of patients & $\mathbf{0 . 0 4 4}$ \\
\cline { 2 - 3 } & The correlation coefficient & $\mathbf{2 6}$ \\
\cline { 2 - 3 } & p-value & $\mathbf{- 0 . 2 7 1}$ \\
\cline { 2 - 3 } & Number of patients & $\mathbf{0 . 1 8 1}$ \\
\hline \multirow{2}{*}{ Total plaques } & & $\mathbf{2 6}$ \\
\cline { 2 - 3 } & The correlation coefficient & $\mathbf{0 . 0 6 3}$ \\
\cline { 2 - 3 } & P-value & $\mathbf{2 6}$ \\
\cline { 2 - 3 } & Number of patients & \\
\end{tabular}

Table 8. Relationship of serum vitamin D level with brain, cervical spinal cord and total plaques in winter

\begin{tabular}{|c|c|c|}
\hline \multicolumn{2}{|c|}{} & Serum Vitamin D levels \\
\hline \multirow{2}{*}{ Brain plaque } & The correlation coefficient & $\mathbf{- 0 . 5 1 0}$ \\
\cline { 2 - 3 } & p-value & $\mathbf{0 . 0 3 6}$ \\
\cline { 2 - 3 } & Number of patients & $\mathbf{1 7}$ \\
\hline Cervical spinal cord plaque & The correlation coefficient & $\mathbf{- 0 . 7 1 0}$ \\
\cline { 2 - 3 } & p-value & $\mathbf{0 . 0 0 1}$ \\
\cline { 2 - 3 } & Number of patients & $\mathbf{1 7}$ \\
\hline \multirow{2}{*}{ Total plaques } & & $\mathbf{- 0 . 7 1 2}$ \\
\cline { 2 - 3 } & The correlation coefficient & $\mathbf{0 . 0 0 1}$ \\
\cline { 2 - 3 } & P-value & 17 \\
\cline { 2 - 3 } & Number of patients & \\
\hline
\end{tabular}

one of the other factors for MS attacks. On the other hand, high occurrence of disease in coldest months could be related to infection disease such as sinusitis. ${ }^{20,38,39}$ Comparison of serum levels of vitamin D in different seasons showed that vitamin D levels were significantly lower in autumn $(214.41 \mathrm{mmol} / \mathrm{L})$ than the level of vitamin $\mathrm{D}$ in winter $(33.58 \mathrm{mmol} / \mathrm{L}),(\mathrm{P}=0.018)$. Serum vitamin $\mathrm{D}$ levels did not show statistically significant differences in other seasons. Since this finding is not consistent with the amount of sunlight, comparing the results with other findings is difficult because different criteria have been used of for evaluation of vitamin D level and because serum levels of vitamin D many be affected by various environmental factors, e.g., duration of sunlight and average monthly temperature. In the current study, a significant correlation was found between serum vitamin D level and cervical spinal cord plaques, while no relationship was observed between serum vitamin D level and number of brain plaque. In addition, a reverse association was revealed between number of cervical spinal cord plaques and low level serum vitamin D in spring. On the other hand, we found a correlation between brain plaque and low level of serum vitamin $\mathrm{D}$ in autumn. Taken together, a statistically significant relationship was demonstrated between serum vitamin D levels (low level) and number of plaques in winter but not overall outcomes. As indicated above, the contradiction in these findings eliminates the possibility of providing a logical interpretation in comparison with those of the previously reported investigations, because the nature of diagnostic methods is different for revealing MS exacerbations in studies and results may be affected by various environmental factors (e.g., duration of sunlight, mean monthly temperatures and regional difference of MS prevalence.20 The reasonable seasonal variation of the vitamin $\mathrm{D}$ serum concentrations was not 
revealed in the present study. In contrast with our results, several other investigations conducted in the northern hemisphere reported strong seasonal variation of the vitamin D serum concentrations in patients with MS. ${ }^{40-42}$ Our findings are in agreement with some previous studies that reported conflicting results. ${ }^{13,14,43,44}$ A limitation of our study is that it is based upon single clinical center data, which is limited by small sample size. It should be taken into consideration that many reports showed temporal variation in onset of relapses with different diagnostic and inclusion criteria that may affect the findings. Additionally, the definition of recurrence has been different between prospective and retrospective studies. In the present study, the association of season with the prevalence of relapse cases cannot be verified, and may be due to the interference of other environmental factors, including infections. Although the mean serum levels of vitamin D are inversely correlated with the incidence of relapses in winter. However, the values obtained in the spring do not confirm such an inverse relationship. Overall, no significant relationship was found between serum vitamin D levels and number of plaques, bot (brain and cervical spinal cord plaques and total plaques). One limitation of the results here was that this study didn't consider factors such as sun exposure, body mass index and longitudinal vitamin $\mathrm{D}$ serum concentrations. Therefore, large multi-center studies, cohorts, and randomized trials are required to determine possible effects of vitamin D in MS.

\section{List of acronyms}

APCs - Antigen-presenting cells

CNS - central nervus system

MRI - Magnetic Resonance Imaging

MS - Multiple sclerosis

\section{Authors contributions}

SHSS, AM, ARD, MGH, and BHGH conceived the study, performed the experiment, analyzed the data, wrote the paper and helped to editing the manuscript.

\section{Acknowledgments}

None.

\section{Funding}

No funding was obtained for this project.

\section{Conflict of Interest}

The authors declare no conflicts of interests.

\section{Ethical Publication Statement}

We confirm that we have read the Journal's position on issues involved in ethical publication and affirm that this report is consistent with those guidelines.

\section{Corresponding Author}

Sharareh Sanei Sistani, Department of Radiology, School of Medicine, Zahedan University of Medical Sciences, Zahedan, Iran

Email: sanei1345@yahoo.com

E-mails of co-authors

Ali Moghtaderi: moghtaderi@zaums.ac.ir

Ali Reza Dashipoor: ar_dashipoor@yahoo.com

Maryam Ghaffarpoor:

Maryamghaffarpoormd@yahoo.com

Bahareh Heshmat Ghahderijani:

bahar.heshmatmd@gmail.com

\section{References}

1. Barakos JA. White matter and neurodegenerative diseases. In: Brant WE, Helms CA. Editors. Fundamental of Diagnostic Radiology. Third edition. Lippincott Williams \& Wilkins 2007; Chapter 7:184-212.

2. Lan B. Leuko encephalopathies and demyelinating Disease. In: Haga JR et al. Editors. CT and MRI of the whole body. Fifth edition. Mosbey 2009:42967.

3. Ascherio A, Munger KL. Environmental risk factors for multiple sclerosis. Part II: Noninfectious factors. Ann Neurol 2007;61:504-13.

4. Simpson S Jr, Taylor B, Blizzard L, et al. Higher 25-hydroxyvitamin $\mathrm{D}$ is associated with lower relapse risk in multiple sclerosis. Ann Neurol 2010;68:193-203.

5. Mehta BK. New hypotheses on sunlight and the geographic variability of multiple sclerosis prevalence. J Neurol Sci 2010;292:5-10.

6. Simpson S Jr, Blizzard L, Otahal P, et al. Latitude is significantly associated with the prevalence of multiple sclerosis: a meta-analysis. J Neurol Neurosurg Psychiatry 2011;82:1132-41.

7. Risco J, Maldonado H, Luna L, et al. Latitudinal prevalence gradient of multiple sclerosis in Latin America. Mult Scler 2011;17:1055-9.

8. Hollingworth S, Walker $\mathrm{K}$, Page A, et al. Pharmacoepidemiology and the Australian regional prevalence of multiple sclerosis. Mult Scler 2013;19:1712-6.

9. Runia TF, Hop WCJ, de Rijke YB, et al. Lower serum vitamin $\mathrm{D}$ levels are associated with a higher relapse risk in multiple sclerosis. Neurology 2012;79:261-6.

10. Smolders J, Menheere $\mathrm{P}$, Kessels A, et al. Association of vitamin D metabolite levels with relapse rate and disability in multiple sclerosis. Mult Scler 2008;14:1220-4.

11. Mowry EM, Krupp LB, Milazzo M, et al. Vitamin $\mathrm{D}$ status is associated with relapse rate in pediatriconset multiple sclerosis. Ann Neurol 2010;67:618624 
12. Bamford CR, Sibley WA, Thies C. Seasonal variation of multiple sclerosis exacerbations in Arizona. Neurology 1983;33:697-701.

13. Goodkin DE, Hertsgaard D. Seasonal variation of multiple sclerosis exacerbations in North Dakota. Arch Neurol 1989;46:1015-8.

14. O'Reilly MA, O'Reilly PM. Temporal influences on relapses of multiple sclerosis. Eur Neurol 1991;31:391-5.

15. Mehrnahad M, Soleimantabar H, Sanei Taheri M, Ghahderijani BH. Pre-labor rupture of uterus at 32 weeks with extrusion of fetus with intact amniotic sac: a case report. J Inter Trans Med, June 2019;7:99-102.

16. Mehrnahad M, Soleimantabar H, Ebrahimi A, Ghahderijani BH. Circumferential meningioma of the cervical spinal cord with widespread intracranial extension. J Res Med Dent Sci 2019;7:44-6.

17. Jamaati HR, Heshmat B, Tamadon R, et al. Association between Severity of Chronic Obstructive Pulmonary Disease and Lung Function Tests. Tanaffos 2013;12:36-41.

18. Auer DP, Schumann EM, Kümpfel T, et al. Seasonal fluctuations of gadolinium-enhancing magnetic resonance imaging lesions in multiple sclerosis. Ann Neurol 2000;47:276-7.

19. Abella-Corral J, Prieto JM, Dapena-Bolano D, et al. Seasonal variations in the outbreaks in patients with multiple sclerosis. Rev Neurol 2005;40:394-6.

20. Ogawa G, Mochizuki H, Kanzaki M, et al. Seasonal variation of multiple sclerosis exacerbations in Japan. Neurol Sci 2004;24:417-9.

21. Koziol JA, Feng AC. Sesonal variations in exacerbations and MRI parameters in relapsingremitting multiple sclerosis. Neuroepidemiology 2004;23:217-23.

22. Ramagopalan SV, Dobson R, Meier UC, Giovannoni G. Multiple sclerosis: risk factors, prodromes, and potential causal pathways. Lancet Neurol 2010;9:727-39.

23. Handel AE, Giovannoni G, Ebers GC, Ramagopalan SV. Environmental factors and their timing in adult-onset multiple sclerosis. Nat Rev Neurol 2010;6:156-66.

24. Goodin DS. The causal cascade to multiple sclerosis: a model for MS pathogenesis. PLoS One 2009;4:e4565.

25. Hagenau T, Vest R, Gissel TN, et al. Global vitamin $\mathrm{D}$ levels in relation to age, gender, skin pigmentation and latitude: an ecologic metaregression analysis. Osteoporos Int 2009;20:13340.

26. Hernan MA, Olek MJ, Ascherio A. Cigarette smoking and incidence of multiple sclerosis. Am J Epi 2001;154:69-74.

27. Levin LI, Munger KL, Rubertone MV, et al. Temporal relationship between elevation of
Epstein-Barr virus antibody titers and initial onset of neurological symptoms in multiple sclerosis. JAMA 2005;293:2496-500.

28. Correale J, Ysrraelit MC, Gaitán MI. Immunomodulatory effects of Vitamin $\mathrm{D}$ in multiple sclerosis. Brain 2009;132:1146-60.

29. Di Rosa M, Malaguarnera M, Nicoletti F, Malaguarnera L. Vitamin D3: a helpful immunomodulator. Immunology 2011;134:123-39.

30. McFarland HF, Martin R. Multiple sclerosis: a complicated picture of autoimmunity. Nat Immunol 2007;8:913-9.

31. Piemonti L, Monti P, Sironi M, et al. Vitamin D3 affects differentiation, maturation, and function of human monocyte-derived dendritic cells. J Immunol 2000;164:4443-51.

32. Almerighi C, Sinistro A, Cavazza A, et al. 1Alpha,25-dihydroxyvitamin D3 inhibits CD40Linduced pro-inflammatory and immunomodulatory activity in human monocytes. Cytokine 2009;45:190-7.

33. Lemire JM, Adams JS, Sakai R, Jordan SC. 1alpha,25-dihydroxyvitamin D3 suppresses proliferation and immunoglobulin production by normal human peripheral blood mononuclear cells. J Clin Invest 1984;74:657-661.

34. Chen S, Sims GP, Chen XX, et al. Modulatory effects of 1,25-dihydroxyvitamin D3 on human B cell differentiation. J Immunol 2007;179:1634-47.

35. Dörr J, Döring A, Paul F. Can we prevent or treat multiple sclerosis by individualised vitamin D supply? EPMA J 2013;4:4.

36. Ascherio A, Munger KL, White R, et al. Vitamin D as an early predictor of multiple sclerosis activity and progression. JAMA Neurol 2014;71:306-14.

37. Mowry EM, Waubant E, McCulloch CE, et al. Vitamin D status predicts new brain magnetic resonance imaging activity in multiple sclerosis. Ann Neurol 2012;72:234-40.

38. Sibley WA, Bamford CR, Clark K. Clinical viral infections and multiple sclerosis. Lancet 1985;1:1313-5.

39. Gay D, Dick G, Upton G. Multiple sclerosis associated with sinusitis: case-controlled study in general practice. Lancet 1986;1:815-819.

40. Soilu-Hänninen M, Laaksonen M, Laitinen I, et al. A longitudinal study of serum 25-hydroxyvitamin $\mathrm{D}$ and intact parathyroid hormone levels indicate the importance of vitamin $\mathrm{D}$ and calcium homeostasis regulation in multiple sclerosis. J Neurol Neurosurg Psychiatry 2008;79:152-7.

41. Løken-Amsrud K, Holmøy T, Bakke SJ, et al.,Vitamin D and disease activity in multiple sclerosis before and during interferon- $\beta$ treatment. Neurology 2012;79:267-73.

42. SaltytėBenth J, Myhr KM, Løken-Amsrud KI, et al. Modelling and prediction of 25-hydroxyvitamin D levels in Norwegian relapsing-remitting multiple 


\title{
25-OH vitamin D serum levels in Multiple Sclerosis
}

\author{
Eur J Transl Myol 29 (3): 268-275, 2019
}

sclerosis patients. Neuroepidemiology 2012;39:8493.

43. Sibley WA, Foley JM. Seasonal variation in multiple sclerosis and retrobulbar neuritis in Northeastern Ohio. Trans Am Neurol Assoc 1965;90:295-7.

44. Sosa Enriguez M, Betancor Leon P, Rosas C, et al. Multiple sclerosis in the province of Las Palmas

(Spanish). Archivos de Neurobiologia
1983;46:161-6.

Submission: June, 26, 2019

Revision received: July 02, 2019

Acceptance: July 05, 2019 